\title{
Morphometric analysis on sagitta, asteriscus and lapillus of Shortnose Mojarra Diapterus brevirostris (Teleostei: Gerreidae) in Cuyutlan coastal Lagoon, Colima, Mexico
}

Análisis morfométrico de la sagitta, el asteriscus y el lapillus de la mojarra malacapa Diapterus brevirostris (Teleostei: Gerreidae) de la laguna costera de Cuyutlán, Colima, México

\section{Manuel Gallardo-Cabello ${ }^{1}$, Elaine Espino-Barr², Esther Gpe. Cabral-Solís ${ }^{2}$, Marcos Puente-Gómez ${ }^{2}$ and Arturo Garcia-Boa ${ }^{2}$}

\begin{abstract}
${ }^{1}$ Instituto de Ciencias del Mar y Limnología, Universidad Nacional Autónoma de México, Av. Ciudad Universitaria 3000, Col. Copilco, México, D.F. C.P. 04360, México

${ }^{2}$ INAPESCA, CRIP-Manzanillo. Playa Ventanas s/n, Manzanillo, Colima. C.P. 28200. México. elespino@gmail.com

Resumen.- Se estudiaron la morfología, la morfometría y los anillos de crecimiento de los otolitos: sagitta, asteriscus y lapillus de Diapterus brevirostris de la laguna de Cuyutlán, Colima, México. Las muestras se obtuvieron de la captura comercial de abril 2010 a julio 2012. Se analizaron las diferencias entre derecho e izquierdo y entre sexos de los tres pares de otolitos. Las relaciones entre la longitud total del pez y la longitud y anchura del otolito mostraron que estas estructuras pueden utilizarse para determinar la edad en los peces. En todos los casos se observó que el crecimiento en los otolitos es excéntrico con respecto al núcleo. Se identificaron 6 anillos de crecimiento en las sagittae y en los asterisci. Debido a su grosor, estas marcas no se observaron en los lapilli. El crecimiento de las sagittae y los lapilli es mayor en machos que en hembras en el intervalo de clases de tallas de 160 a $320 \mathrm{~mm}$ de longitud total. Sin embargo, se observó que el crecimiento de los asterisci es mayor en hembras que en machos en las tallas de 180 a $320 \mathrm{~mm}$.
\end{abstract}

Palabras clave: Otolitos, anillos de crecimiento, determinación de edad, Diapterus brevirostris

Abstract.- Morphology, morphometry and growth rings of the otoliths: sagitta, asteriscus and lapillus of Diapterus brevirostris from Cuyutlán Lagoon in Colima, Mexico were studied. The samples were obtained from the commercial catch from April 2010 to July 2012. Right and left and sex differences of the three pairs of otoliths were analyzed. Relations between total length of the fish and length and width of the otolith showed that these structures can be used to determine age in fish. Growth in otoliths is eccentric according to the core in all cases. Six growth rings were identified in sagittae and asterisci. These marks could not be seen in lapilli because of the thickness of this structure. Growth of sagittae and lapilli is faster in males than females of 160 to $320 \mathrm{~mm}$ total length. Nonetheless, it was observed that growth in asterisci is faster in females than in males of 160 to $320 \mathrm{~mm}$.

Key words: Otolith, growth rings, age determination, Diapterus brevirostris

\section{INTRODUCTION}

Shortnose mojarra Diapterus brevirostris (Sauvage, 1879) used to be named Peruvian mojarra D. peruvianus (Cuvier, 1830) (González-Acosta et al. 2007). Its common name, Peruvian mojarra has also been changed for Shortnose mojarra (pers. comm. Héctor Espinosa-Pérez ${ }^{1}$ ). It is distributed in Eastern Pacific from south part of the Gulf of California to Peru. Its habitat is near the shore, on sandy bottoms. Juveniles penetrate brackish coastal lagoons. The species is mainly carnivorous; it consumes small benthic invertebrates and fish, also small amounts of vegetable mater (Allen \& Robertson 1994, Bussing 1995).

This species is an important fishery resource, caught by gill nets and cast nets by artisanal fishers, although it is not the target species. During 2011 its production in Mexico was 62 thousand tons; in the Mexican Pacific coast the production was $62 \%$ and Colima registered 345 ton (1\% of the Pacific production). The price at the market is of $\$ 30.00$ Mexican pesos ( $\$ 2.30$ US dollar).

${ }^{1}$ Héctor Espinosa Pérez, Colección Nacional de Peces, Instituto de Biología, Universidad Nacional Autónoma de México, Ciudad de México, México. hector@unam.mx 
Studies on Gerreidae family taxonomy have been made by Tapia-García \& Ayala-Pérez (1996-1997), GonzálezAcosta et al. (2005, 2007); distribution patterns of this family have been studied by Martínez-González (1983), Avilés-Torres et al. (2001), Halpern (2004), CaballeroVázquez et al. (2005), Castillo-Rivera et al. (2005), and Ospina-Arango et al. (2008). Álvarez-Pliego (2009) carried out a study on phylogenetic and biographic analysis of the genus Diapterus. Jiménez-Rosenberg (2003) studied D. peruvianus larvae and Hernández et al. (2012) larvae of Eugerres mexicanus. Gómez del Prado-Rosas et al. (2007) reported parasites trematoda in Gerres cinereus.

Aguirre-León \& Díaz-Ruíz (2000, 2006) studied length structure, gonadic maturation and feeding habits of Eugerres plumieri and D. rhombeus.

Rubio et al. $\left(2004^{2}\right)$ reported data on growth in cages of D. peruvianus and Eucinostomus currani in Buenaventura Bay, Colombia. Díaz-Murillo (2010) studied otolith sagitta of several Gerreidae species. Age determination of $G$. cinereus was calculated by ÁlvarezHernández (1999) and Jones et al. (2010), using length frequency analysis and scales. Herrera-Reveles et al. (2012) studied daily growth increments and RNA/DNA ratios in juveniles of Eucinostomus argenteus in the Caribbean sea of Venezuela. Chen et al. (2007) analyzed mitocondrial DNA in relationships on phylogenetic studies.

Otoliths are hard structures of specialized crystals that are part of the lateral acoustic system of fish. They are immersed in the membranous labyrinth at each side of the brain, and act as equilibrium and audition organs. They are formed mainly by crystalized calcium carbonate inserted in an organic protein mater. Analyses on otoliths composition and physiology on different species have been done by Hickling (1931), Sasaki \& Miyata (1955), Carlström (1963), Mugiya (1964, 1966 a, b), Degens et al. (1969) and Gallardo-Cabello (1986).

Studies of the three pairs of otoliths (sagitta, asteriscus and lapillus) have been done on larvae of different species by Barkman (1978), Victor \& Brothers (1982), Brothers et al. (1983), Solomon et al. (1985), Bolz \& Lough (1983, 1988), Lagardere (1989), Suthers et al. (1989) and David et al. (1994), describing its parts and daily growth rings.
Adult fish studies on morphometry related to body length have been carried out by Espino-Barr et al. (2006), Gallardo-Cabello et al. (2006), Santana-Hernández et al. (2008), Granados-Flores et al. (2010) and Gallardo-Cabello et al. (2011), on diverse species. Study of otoliths can also be useful in the determination of antropogenic contamination (Kamaruzzaman et al. 2011).

Otoliths have mostly been used to determine age groups of the stock and growth analysis, one of the fundamental parameters to formulate models on maximum sustainable captures, yield per recruit, predictions and catch simulations (Campana \& Neilson 1985, Sparre \& Venema 1995, Gallardo-Cabello et al. 2003, MascareñaOsorio et al. 2003, Begg et al. 2005, Espino-Barr et al. 2005, Gallardo-Cabello et al. 2007, Espino-Barr et al. 2010). These models are used to help regulate the fishery administration to avoid overproduction, capturing organisms that have reproduced at least once and limiting young specimen still sexually immature (Ehrhardt 1981, Stevensen \& Campana 1992, Berg et al. 2005, Francis et al. 2005). Studies on fisheries are of great importance, and should be thoroughly assessed for their sustainability (Eide \& Wikan 2010). This is why the analysis of otoliths in age determination is one of the most important bases in population dynamics studies.

This study presents for the first time, a study on morphology and morphometry analysis on otoliths of Diapterus brevirostris, and also growth ring identification in the otoliths: sagittae, asterisci and lapilli.

We want to highlight results presented in this study which gives valuable information on phylogenetic and evolutive relations of the species and its ecological niche width. Development of the superior (lapillus) and inferior (sagitta and asteriscus) parts of the internal ear differs in bony fish according to its habitat. Pelagic fish that are fast swimmers require a better tridimensional orientation and present a better developed superior part than demersal fish, where the inferior part has a higher development. Sagitta and asteriscus are related to sound reception, gravity and angular acceleration, while lapillus is associated to equilibrium (Holst et al. 1950, Lowenstein 1957, Lagler et al. 1962, Gallardo-Cabello 201233).

\footnotetext{
${ }^{2}$ Rubio E, J Loaiza \& CJ Moreno. 2004. Crecimiento y sobrevivencia de dos especies de mojarras Diapterus peruvianus y Eucinostomus currani criadas en jaulas flotantes en la Bahía de Buenaventura. Mem. III Congreso Iberoamericano Virtual de Acuacultura. CIVA. Zaragoza, España. http://www.iiap.org.pe/publicaciones/CDs/MEMORIAS_VALIDAS/pdfs/Rubio3.pdf

${ }^{3}$ Gallardo-Cabello M, E Espino-Barr, A. Garcia-Boa, EG Cabral-Solís \& M Puente-Gómez. 2012. Diferencias morfométricas de las sagittae en seis especies de la pesca comercial de Manzanillo, Colima. XIII Congreso Nacional de Ictiología, San Cristóbal de Las Casas, Chiapas 29 octubre a 2 noviembre 2012, p. 31.
} 
Also, the present study shows a detailed description of sagittae of Diapterus brevirostis that will allow their identification in stomach contents of its predators, since otoliths are unique to each species and they preserve longer than the soft tissues, even after having passed through the digestive tract of the predators (Le Boeuf \& Bonnell 1980, Le Boeuf et al. 1983, Gallo-Reynoso \& Aurioles-Mendoza 1984, Aurioles 1988). Likewise, otoliths of fish can be recognized in regurgitated and copro material in studies of marine mammals, from which the collection of stomachs is not possible (Laevesteu \& Favorite 1981, Bailey \& Ainley 1982, Brown \& Pierce 1997).

\section{Materials AND METHODS}

From April 2010 to July 2012, 401 organisms of Diapterus brevirostris were taken directly from the commercial captures of Cuyutlan Lagoon fishery in Manzanillo, Colima, Mexico. Individuals were captured with cast net and gillnet in order to obtain different lengths and age groups. Organisms were taken to the lab to sample: for each individual, total length (TL, $\mathrm{mm}$ ) and sex were registered.

Sagittae, asterisci and lapilli were obtained through a transverse cut in the ventral cranial cavity, the brain was removed and the left and right semicircular canals were extracted (Fig. 1). Otoliths were separated, cleaned, rinsed with water and stored dry in Eppendorf tubes labeled with number, date, total length and sex.
The structure of otoliths was studied with a dissection microscope (10x). A description of the labyrinth system and sagittae was made with the terminology of the glossary of Secor et al. (1992). The same concepts were applied to the description of asterisci and lapilli according to Gallardo-Cabello et al. (2006) and Espino-Barr et al. (2006).

Data on length and width were registered for each otolith through their observation in a stereoscopic microscope with a graduated ocular lens (10x). Measures were taken on the right and left aspect for the three pairs.

Otolith sample size was calculated with the formula described by Daniel (1991), $n=\left(\mathrm{z}^{*} \sigma\right) /\left(\mathrm{d}^{*} \mu\right)$. Constants of the relationships of the sagittae were calculated for rostrum length (SL) and width (SW). For asterisci and lapilli the indexes of the constants of the relationship were obtained for length (L) and width (W). Relationships between total length of the fish and all the measures of the three otoliths were also recorded. Regressions were done by the least squares analysis (Mendenhall 1987).

For the evaluation of the relations and the analysis of the possible morphometric differences between the otoliths of males and females, a one way variance analysis (ANOVA) was carried out (Zar 1996).

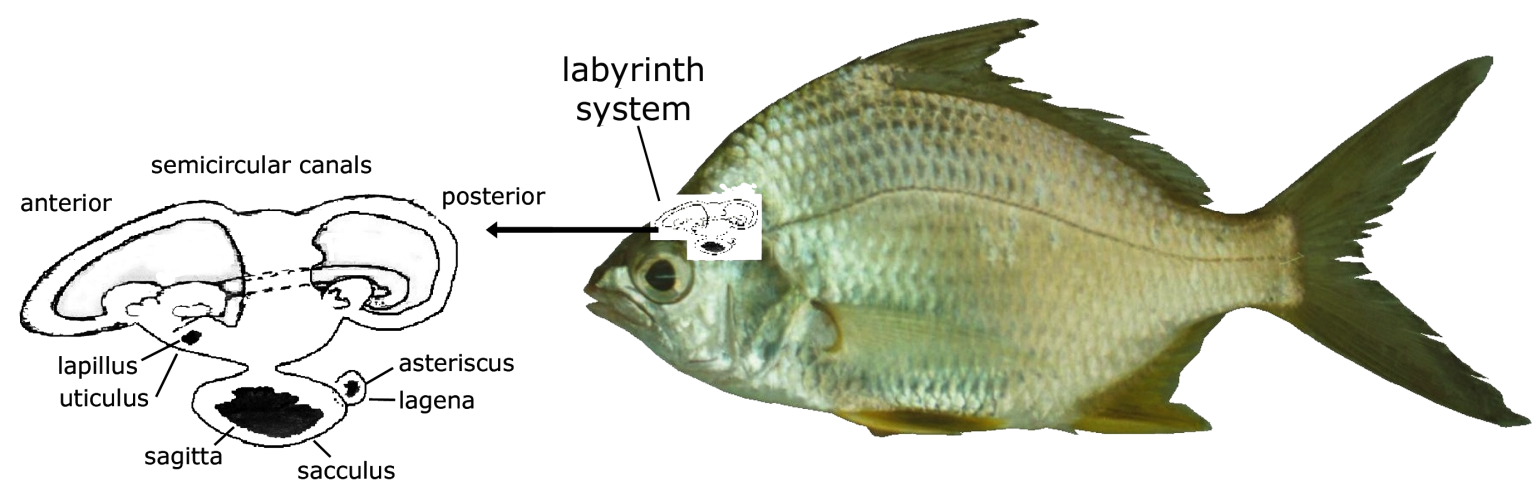

Figure 1. Diapterus brevirostris showing the position of the labyrinth system and drawing of the semicircular cannals and the 3 otoliths / Posición del sistema laberíntico en Diapterus brevirostris y esquema de los canales semicirculares y los 3 otolitos 
Growth ring identification was done observing the sagittae and the asterisci in the stereoscopic microscope (1x and 2x) with transmitted light and the average size of each ring was calculated. Rings were validated by observing them all around the structure, by determining marginal increment according to the month of year and relating the number of rings to the size of the fish (Joseph 1962, Heald \& Griffiths 1967, Beamish \& McFarlane 1983, Jearld 1983, Casselman 1983).

\section{Results}

The information on otoliths of Diapterus brevirostris is completely original, and no other studies to consult were found to compare and discuss data from this study.

\section{LABYRINTH SYSTEM OF DIAPTERUS BREVIROSTRIS}

The semicircular canals are a tubular system that forms the membranous labyrinth (Fig. 2); these canals are 3: anterior vertical canal, posterior vertical canal and horizontal canal. These tubes form chambers containing the otoliths, the lapillus is in the utriculus, the sagitta is in the sacculus (Fig. 2) and the asteriscus is in the lagena (Fig. 2). The otoliths contained in each chamber are immersed in a liquid called endolymph (Lagler et al. 1962).

Otoliths are connected with the macula through a type of nerve cells named neuromasts. The macula enters in the acoustic canal of the lapillus, sagitta and asteriscus (Figs. 2 and 3) and nourish the otoliths with the deposition of protein and calcium carbonate.

The largest otolith in $D$. brevirostris is the sagitta, that reaches a total length of $10.17 \mathrm{~mm}$, while asteriscus measures $1.75 \mathrm{~mm}$ and lapillus $1.93 \mathrm{~mm}$ in specimens of $300 \mathrm{~mm}$ total length.
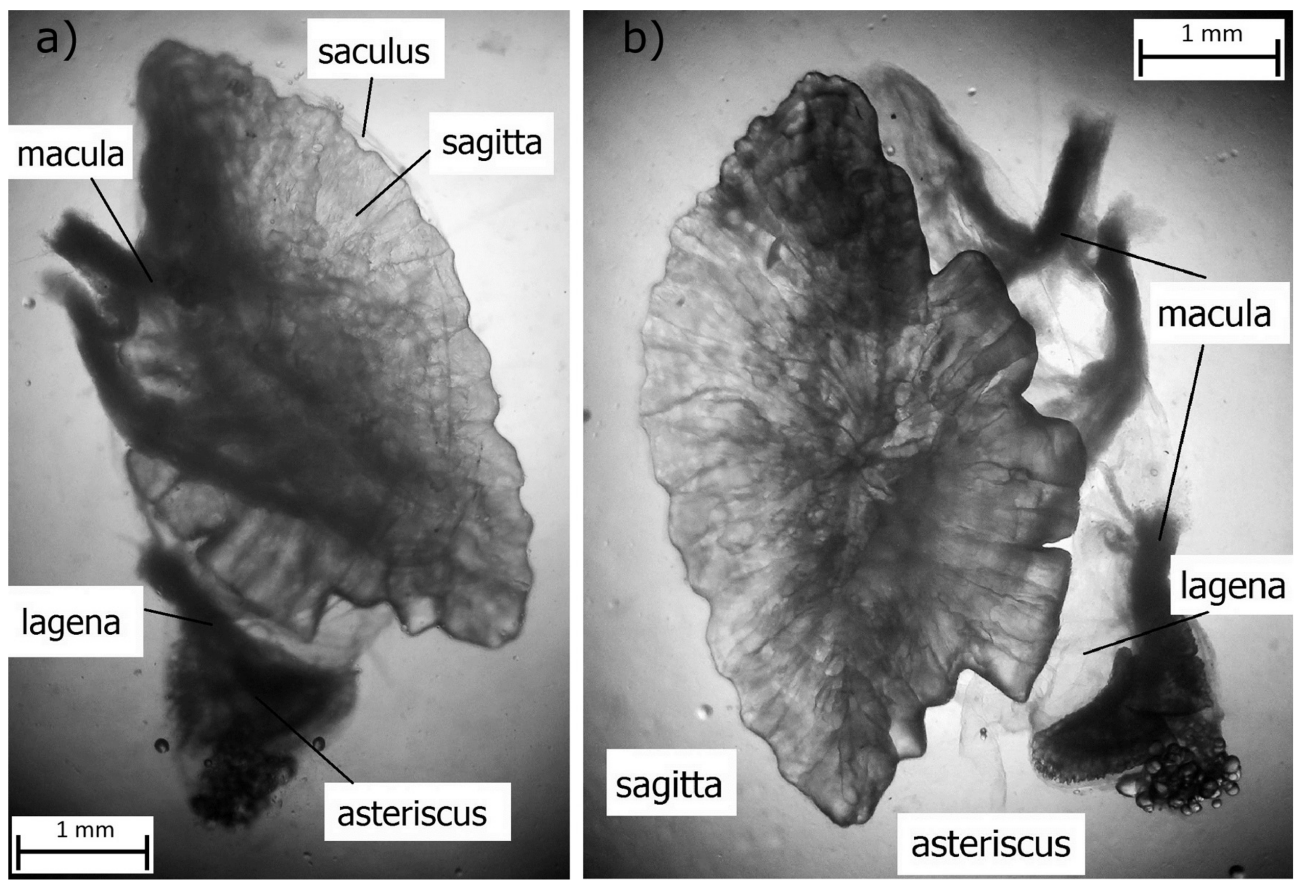

Figure 2. Section of the membranous labyrinth of an individual of Diapterus brevirostris $(200 \mathrm{~mm}$ of total length, increased 12.4 times), showing the sagitta included in the sacculus, the asteriscus in the lagena with sections of the macula, a) internal aspect, b) external aspect / Sección de la membrana del laberinto de un individuo de Diapterus brevirostris (de $200 \mathrm{~mm}$ de longitud total, incremento de 12,4 veces), que muestra la sagitta dentro del sacculus, el asteriscus en la lagena y secciones de la mácula, a) cara interna, b) cara externa 


\section{DESCRIPTION OF THE OTOLITHS OF SHORTNOSE MOJARRA DIAPTERUS BREVIROSTRIS}

\section{DESCRIPTION OF THE SAgITTA}

A prominent rostrum is present in the anterior margin of the sagitta, it does not have an excisura major and therefore no antirostrum (Figs. 2 and 3). As the fish ages, the shape of the sagitta varies and lengthens. Its form can vary in the right and left sagittae of the same specimen and can also be totally different between individuals.

The posterior section of the sagitta shows a rounded postrostrum that tends to lengthen as age increases. There is not excisura minor and therefore no pararostrum (Figs. 2 and 3 ).

The dorsal margin shows at the beginning a notch, followed by a projected stepped structure which increased its size as the fish ages. The profile of the dorsal margin also shows many irregularities, similar to denticles that extend from the rostrum to the postrostrum. The ventral side shows some irregularities such as indentations but it tends to be rectilinear from the upper part of the otolith to more than the middle part of the postrostrum.

Sagitta's internal aspect is convex, feature that increases with age; the acoustic channel goes all long the otolith surface (Fig. 3) increasing its width from the rostrum to the postrostrum. The acoustic channel is not divided into the cauda and the ostium.

The external aspect of the sagitta is concave, slightly thicker in the middle part of the sagitta than in the extremes of the otolith (Fig. 2). Growth rings appear more clearly in an area that goes from the middle part of the sagitta to the postrostrum, they can be seen as dark lines following the shape of the otolith. Average width of the sagitta is 1.83 times its average length.

There was no statistical difference found between sizes of right and left sagitta $\left(F^{\prime}{ }_{0.05}(2,109=3.929)=0.034\right)$; also between otolith sizes of males and females $\left(F^{\prime}{ }_{0.05}(2,39=\right.$ ${ }_{4.098)}=0.292$ ).

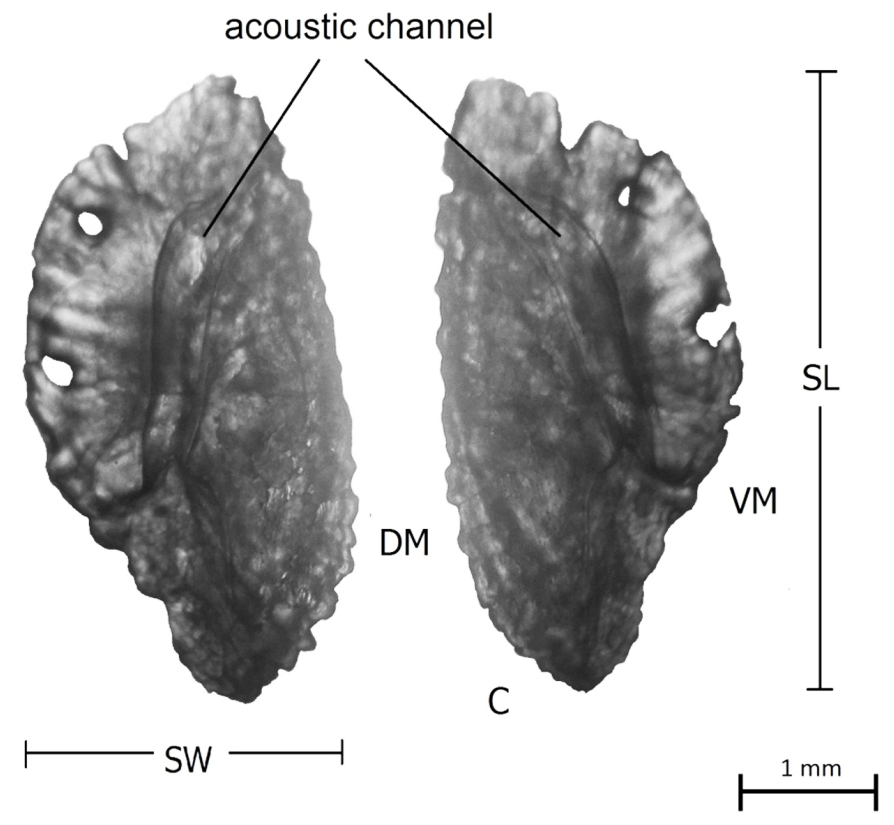

Figure 3. Internal side of the right and left sagitta of Diapterus brevirostris showing the acoustic channel, $\mathrm{SL}=$ rostrum length, $\mathrm{C}=$ postrostrum, $\mathrm{DM}=$ dorsal margin, $\mathrm{VM}=$ ventral margin, $\mathrm{SW}=$ otolith width $/ \mathrm{Cara}$ interna de la sagitta derecha e izquierda de Diapterus brevirostris, se muestra el canal acústico, SL= longitud del rostrum, $\mathrm{C}=$ postrostrum, $\mathrm{DM}=$ margen dorsal, $\mathrm{VM}=$ margen ventral, $\mathrm{SW}=$ ancho del otolito 


\section{DESCRIPTION OF THE ASTERISCUS}

The shape of the asterisci did not show differences between right and left, as in the sagittae but can vary between specimens (Fig. 4). Sizes between sexes did not have statistical difference $\left(F^{\prime}{ }_{0.05}(2,38=4.105)=2.505\right)$, and also between right and left there was no statistical difference found $\left(\mathrm{F}_{0.05(2,99=3.934)}^{\prime}=0.206\right)$.

The asteriscus is divided in its anterior margin by a blunt projection in two areas: a dorsal area with a larger surface than the ventral area (Fig. 4). The anterior margin has sections that can be rectilinear from the dorsal to the ventral margins.

The posterior margin is curved and shows a very big and characteristic notch that interrupt the continuity of the posterior margin (Fig. 4). This margin presents a groove all long the dorsal and ventral margin, which divides the otolith in two parts: the first side has a larger sized radius in the external aspect (posterior external margin) interrupted by the notch and the second has a shorter sized radius that forms the posterior internal margin (Fig. 4).

The external aspect of the otolith is convex and the internal aspect is concave, this curvature of the otolith increases as the fish ages. The asteriscus shows small indentations in both aspects (Fig. 4). Its average width is 1.6 times its average length.

\section{DESCRIPTION OF THE LAPILLUS}

The lapillus shows an anterior margin which is pointed and oriented toward the front of the fish. Dorsal and ventral margins run from the anterior margin to the central part of the otolith developing a fan-shaped structure. The ventral margin is rectilinear and smaller and the dorsal edge of this structure is notably larger and rounded (Fig. $5)$. The inner lapillus surface is concave, its curvature increases with age, in the fan shaped structure the otolith is divided in several lobes by radios (Fig. 5b). A sulcus is present in the posterior border which enters in contact with the acoustic macula, it extends all along the dorsal and ventral margins. The outer aspect of the lapillus is convex; their dorsal and ventral margins are smooth (Fig. 5a). Average length of the lapillus is 1.02 times its average width.

The analysis of variance did not show statistical differences between sexes ( $\left.F_{0.05(2,37=4.113)}^{\prime}=0.503\right)$, nor between right and left $\left(\mathrm{F}_{0.05(2,117=3.923)}^{\prime}=0.046\right)$.
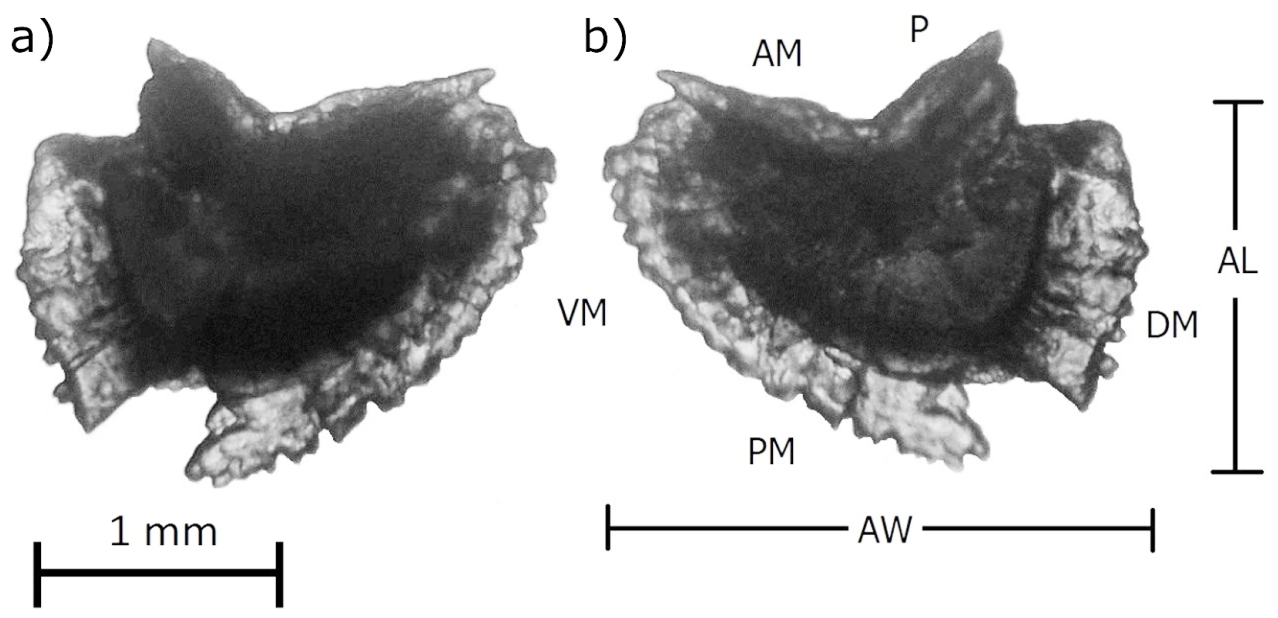

Figure 4. Asteriscus of Diapterus brevirostris: a) external and b) internal aspect. $A M=$ anterior margin, $\mathrm{PM}=$ posterior margin, $\mathrm{DM}=$ dorsal margin and $\mathrm{VM}=$ ventral margin, $\mathrm{AL}=$ length, $\mathrm{AW}=$ width $/$ Asteriscus de Diapterus brevirostris: a) cara externa b) cara interna. $\mathrm{AM}=$ margen anterior, $\mathrm{PM}=$ margen posterior, $\mathrm{DM}=$ margen dorsal y $\mathrm{VM}=$ margen ventral, $\mathrm{AL}=$ largo, $\mathrm{AW}=$ ancho 
a)

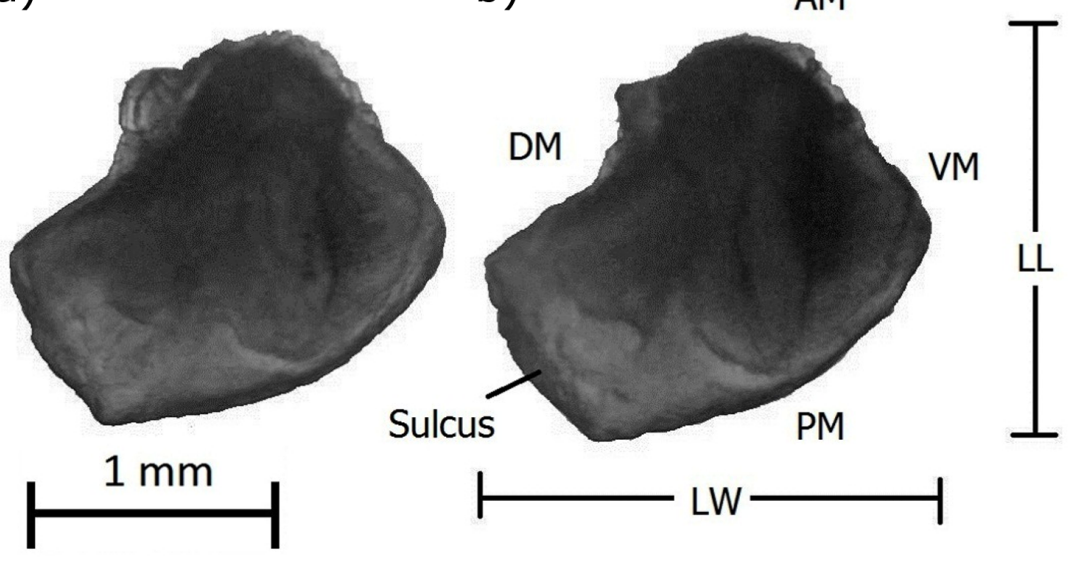

Figure 5. Lapillus of Diapterus brevirostris: a) external and b) internal aspect. $A M=$ anterior margin, $\mathrm{PM}=$ posterior margin, $\mathrm{DM}=$ dorsal margin and $\mathrm{VM}=$ ventral margin, $\mathrm{LL}=$ length, $\mathrm{LW}=$ width $/$ Lapillus de Diapterus brevirostris: a) cara externa y b) cara interna. $\mathrm{AM}=$ margen anterior, $\mathrm{PM}=$ margen posterior, $\mathrm{DM}=$ margen dorsal y $\mathrm{VM}=$ margen ventral, $\mathrm{LL}=$ largo, $\mathrm{LW}=$ ancho

\section{MORPHOMETRIC ANALYSIS OF OTOLITHS OF DiaPTERUS BREVIROSTRIS}

\section{Growth OF THE SAGITTA}

Table 1 shows the relation between the length classes of fish, rostrum and width of sagitta, for the species and sexes. Growth of the rostrum of sagitta are bigger in males from 160 to $320 \mathrm{~mm}$.

Table 1. Calculated measures of rostrum (SL) and width (SW) of sagitta at different size classes of Diapterus brevirostris $(n=394)$ / Medidas calculadas del rostrum (SL) y ancho (SW) del otolito sagitta a diferentes clases de longitud de Diapterus brevirostris $(n=394)$

\begin{tabular}{|c|c|c|c|c|c|c|c|}
\hline \multirow{2}{*}{$\begin{array}{c}\text { Classes } \\
(\mathrm{mm})\end{array}$} & \multirow{2}{*}{$n$} & \multicolumn{2}{|c|}{ Both sexes } & \multicolumn{2}{|c|}{ Females } & \multicolumn{2}{|c|}{ Males } \\
\hline & & $\mathrm{SL}(\mathrm{mm})$ & $\mathrm{SW}(\mathrm{mm})$ & $\mathrm{SL}(\mathrm{mm})$ & $\mathrm{SW}(\mathrm{mm})$ & $\mathrm{SL}(\mathrm{mm})$ & $\mathrm{SW}(\mathrm{mm})$ \\
\hline 80 & & 2.84 & 2.45 & 2.83 & 2.40 & 2.81 & 2.52 \\
\hline 100 & 1 & 3.51 & 2.81 & 3.51 & 2.77 & 3.49 & 2.89 \\
\hline 120 & 14 & 4.19 & 3.15 & 4.18 & 3.11 & 4.17 & 3.22 \\
\hline 140 & 140 & 4.85 & 3.47 & 4.84 & 3.43 & 4.84 & 3.54 \\
\hline 160 & 179 & 5.52 & 3.77 & 5.50 & 3.74 & 5.51 & 3.83 \\
\hline 180 & 43 & 6.17 & 4.06 & 6.16 & 4.03 & 6.17 & 4.11 \\
\hline 200 & 11 & 6.83 & 4.34 & 6.81 & 4.31 & 6.84 & 4.39 \\
\hline 220 & 2 & 7.49 & 4.60 & 7.46 & 4.58 & 7.50 & 4.64 \\
\hline 240 & 3 & 8.14 & 4.86 & 8.11 & 4.84 & 8.16 & 4.90 \\
\hline 260 & & 8.79 & 5.11 & 8.76 & 5.09 & 8.82 & 5.14 \\
\hline 280 & & 9.43 & 5.35 & 9.40 & 5.34 & 9.48 & 5.37 \\
\hline 300 & 1 & 10.08 & 5.59 & 10.05 & 5.58 & 10.14 & 5.60 \\
\hline 320 & & 10.72 & 5.82 & 10.69 & 5.81 & 10.79 & 5.82 \\
\hline
\end{tabular}

The relationship between length and width of sagitta is expressed by the exponent value $b=0.642$, which shows a tendency to a negative allometric growth $\left(n=107, R^{2}=\right.$ $\left.0.818, \mathrm{~F}^{\prime}=460.60\right)$, although the dorsal margin of the sagittae increase the width of the otolith. The results show that the sagitta tends to enlarge as fish grow, because most of the individuals used in this study belong to the $150 \mathrm{~mm}$ class of total length. In the case of sexes, results keep a similar trend and the relations of males are $b=$ $0.606\left(n=29, R^{2}=0.671, F^{\prime}=57.00\right)$, and females $b=0.656$ $\left(n=43, R^{2}=0.847, F^{\prime}=276.25\right)$. The results show that the growth of sagitta is eccentric to the core, that means that when the fish ages, the dorsal edge grows more than the ventral edge, the postrostrum grows more than the rostrum and a larger amount of material accumulates on the inner side than the external aspect of sagitta.

The relationship between fish length and length and width of sagitta is shown in Table 2. The higher value of the allometric index relating fish length to rostrum's length is for the males with a value of $b=0.970$, smaller values are found for the species and females, $b=0.959$ and $b=$ 0.958 , respectively. On the other hand, the higher value of the relation between fish length and rostrum width is for the females with a value of $b=0.637(b=0.625$ for species and $b=0.604$ for males). In all cases, values show that there is a direct proportionality between fish length and sagitta length and width; for that reason sagittae are 
adequate to describe the growth of the organism. In each case, high values of the ANOVA's F' show a strong significance among the structures analyzed. Values of allometric growth rates are below one, due to the difficulty of relating very small structures $(\mathrm{mm})$ with values of total fish length, expressed in centimeters.

Table 2. Relationship between total fish length and rostrum length (SL) and width (SW) of sagitta of Diapterus brevirostris / Relaciones entre el largo total del pez y el largo del rostrum (SL) y el ancho (SW) de la sagitta de Diapterus brevirostris

\begin{tabular}{llccrcr}
\hline \multicolumn{2}{c}{ Total length (mm) } & $\mathrm{a}$ & $\mathrm{b}$ & $\mathrm{n}$ & $\mathrm{R}^{2}$ & \multicolumn{1}{c}{$\mathrm{F}^{\prime}$} \\
\hline SL (mm) & Both & 0.042 & 0.959 & 109 & 0.903 & 991.14 \\
& Females & 0.043 & 0.958 & 41 & 0.968 & 1199.60 \\
& Males & 0.040 & 0.970 & 31 & 0.743 & 86.58 \\
$\mathrm{SW}(\mathrm{mm})$ & Both & 0.159 & 0.625 & 107 & 0.827 & 501.65 \\
& Females & 0.147 & 0.637 & 42 & 0.868 & 263.93 \\
& Males & 0.179 & 0.604 & 30 & 0.798 & 110.83 \\
\hline
\end{tabular}

$\mathrm{a}=$ origin ordinate of relation, $\mathrm{b}=$ slope of relation, $\mathrm{n}=$ number of individuals, $\mathrm{R}^{2}=$ determination index of relation, $\mathrm{F}^{\prime}=$ Fischer relation index.

\section{GROWTH OF THE ASTERISCUS}

The relationship between fish length and length and width of asteriscus is shown in Table 3. In all cases growth length of asteriscus is higher in females than males from lengths of $180 \mathrm{~mm}$ on.

The relationship between the length and width of the otolith is described by the females allometric index $b=$ $1.039\left(n=92, R^{2}=0.880, F^{\prime}=212.31\right)$ with values for species $\left(b=0.944, n=92, R^{2}=0.736, F^{\prime}=251.20\right)$, and males, the latter having a small value of the allometric index of $b=$ $0.877\left(n=27 . R^{2}=0.417, F^{\prime}=17.88\right)$. These results show a trend to an isometric growth in which the increase in width is equal to length, but the asteriscus' growth is eccentric to the core. The dorsal margin grows more than the ventral margin and its anterior border grows more than the posterior border.

Table 4 shows the relationship between fish's total length and length and width of asteriscus. The allometric index value closest to one is for females $b=0.909$ for fish total length and asteriscus width, and $b=0.780$ for fish total length and asteriscus length. Similar values were found for the species: $b=0.750$ and $b=0.872$ for fish total

Table 3. Measures of length (AL) and width (AW) of asteriscus at different length classes of Diapterus brevirostris $(n=394)$ / Medidas del largo (AL) y ancho (AW) del asteriscus a diferentes clases de longitud de Diapterus brevirostris $(n=394)$

\begin{tabular}{|c|c|c|c|c|c|c|}
\hline \multirow{2}{*}{$\begin{array}{c}\text { Classes } \\
(\mathrm{mm})\end{array}$} & \multicolumn{2}{|c|}{ Both sexes } & \multicolumn{2}{|c|}{ Females } & \multicolumn{2}{|c|}{ Males } \\
\hline & $\mathrm{AL}(\mathrm{mm})$ & $\mathrm{AW}(\mathrm{mm})$ & $\mathrm{AL}(\mathrm{mm})$ & $\mathrm{AW}(\mathrm{mm})$ & $\mathrm{AL}(\mathrm{mm})$ & $\mathrm{AW}(\mathrm{mm})$ \\
\hline 80 & 0.65 & 0.89 & 0.64 & 0.87 & 0.74 & 0.97 \\
\hline 100 & 0.77 & 1.09 & 0.76 & 1.07 & 0.84 & 1.15 \\
\hline 120 & 0.88 & 1.27 & 0.87 & 1.26 & 0.93 & 1.32 \\
\hline 140 & 0.99 & 1.46 & 0.98 & 1.45 & 1.02 & 1.48 \\
\hline 160 & 1.10 & 1.64 & 1.09 & 1.64 & 1.10 & 1.64 \\
\hline 180 & 1.20 & 1.81 & 1.20 & 1.83 & 1.18 & 1.79 \\
\hline 200 & 1.30 & 1.99 & 1.30 & 2.01 & 1.26 & 1.94 \\
\hline 220 & 1.39 & 2.16 & 1.40 & 2.19 & 1.33 & 2.09 \\
\hline 240 & 1.49 & 2.33 & 1.50 & 2.37 & 1.40 & 2.23 \\
\hline 260 & 1.58 & 2.50 & 1.59 & 2.55 & 1.46 & 2.37 \\
\hline 280 & 1.67 & 2.66 & 1.69 & 2.73 & 1.53 & 2.51 \\
\hline 300 & 1.76 & 2.83 & 1.78 & 2.90 & 1.59 & 2.65 \\
\hline 320 & 1.84 & 2.99 & 1.87 & 3.08 & 1.65 & 2.78 \\
\hline
\end{tabular}


length and asteriscus length and width, respectively. Smaller values were found for males $b=0582$ and $b=0.762$ for fish total length and asteriscus length and width respectively. Values of the ANOVA's F' show a correlation between the structures analyzed in each case, with a tendency to a direct proportionality between fish length and asteriscus width and length, which allows age group determination based on the number of growth rings in asteriscus to be valid for $D$. brevirostris.

Table 4. Relationship between total fish length and length (AL) and width (AW) of the asteriscus of Diapterus brevirostris / Relaciones entre el largo total del pez y el largo (AL) y ancho (AW) del asteriscus de Diapterus brevirostris

\begin{tabular}{llccccc}
\hline \multicolumn{2}{c}{ Total length $(\mathrm{mm})$} & $\mathrm{a}$ & $\mathrm{b}$ & $\mathrm{n}$ & $\mathrm{R}^{2}$ & $\mathrm{~F}$ \\
\hline \multirow{2}{*}{$\mathrm{AL}(\mathrm{mm})$} & Both sexes & 0.024 & 0.750 & 92 & 0.778 & 315.76 \\
& Females & 0.021 & 0.780 & 31 & 0.865 & 186.41 \\
& Males & 0.057 & 0.582 & 27 & 0.714 & 62.41 \\
$\mathrm{AW}(\mathrm{mm})$ & Both sexes & 0.020 & 0.872 & 92 & 0.870 & 602.67 \\
& Females & 0.016 & 0.909 & 31 & 0.957 & 649.38 \\
& Males & 0.034 & 0.762 & 27 & 0.664 & 49.39 \\
\hline
\end{tabular}

$\mathrm{a}=$ origin ordinate of relation, $\mathrm{b}=$ slope of relation, $\mathrm{n}=$ number of individuals, $\mathrm{R}^{2}=$ determination index of relation, $\mathrm{F}^{\prime}=$ Fischer index of relation

\section{Growth OF THE LAPILLUS}

Table 5 shows the relationship between fish length and length and width of lapillus. As in sagitta, the fastest growth of lapillus occurs in males from 160 to $320 \mathrm{~mm}$.

The best relationship between the length and width of lapillus is described by the species allometric index $b=0.766$ $\left(n=118, R^{2}=0.739, F^{\prime}=328.86\right)$, smaller indexes were found for males: $b=0.721\left(n=37, R^{2}=0.702, F^{\prime}=82.45\right)$, and females $b=0.705\left(n=39, R^{2}=0.741, F^{\prime}=105.77\right)$. These values represent a trend to a negative allometric growth, in which lapillus grows more in length than in width. Lapillus growth is eccentric to the core, which means, the anterior and ventral margins show a higher deposition of growth materials than the posterior and dorsal margins.

The relationship between fish length and the length and width of the lapillus is shown in Table 6. The higher value of the allometric index for fish total length and lapillus length was found for males with a value of $b=0.537$, smaller indexes were found for the species and females: $b=0.516$ and $b=0.509$, respectively. Similar values were found for fish total length and lapillus width: $b=0.489$ for males, $b=$ 0.459 for species and $b=0.400$ for females. These values suggest a trend toward direct proportionality between fish length and lapillus that validates identification of growth rings in this structure of $D$. brevirostris.

Table 5. Measures of length (L) and width (LW) of lapillus at different length classes of Diapterus brevirostris $(\mathbf{n}=\mathbf{3 9 4})$ / Medidas del largo (LL) y ancho (LW) del lapillus a diferentes clases de longitudes de Diapterus brevirostris $(n=394)$

\begin{tabular}{rcccccccc}
\hline \multirow{2}{*}{$\begin{array}{c}\text { Classe } \\
(\mathrm{mm})\end{array}$} & \multicolumn{2}{c}{ Both sexes } & & \multicolumn{2}{c}{ Females } & & \multicolumn{2}{c}{ Males } \\
\cline { 2 - 3 } \cline { 7 - 8 } \cline { 7 - 8 } & AL $(\mathrm{mm})$ & AW $(\mathrm{mm})$ & & AL $(\mathrm{mm})$ & AW $(\mathrm{mm})$ & & AL $(\mathrm{mm})$ & AW $(\mathrm{mm})$ \\
\hline 80 & 0.98 & 1.02 & & 0.98 & 1.08 & & 0.97 & 1.00 \\
100 & 1.10 & 1.13 & & 1.10 & 1.18 & & 1.09 & 1.12 \\
120 & 1.20 & 1.23 & & 1.21 & 1.27 & & 1.21 & 1.22 \\
140 & 1.30 & 1.32 & & 1.31 & 1.35 & & 1.31 & 1.31 \\
160 & 1.40 & 1.41 & & 1.40 & 1.42 & & 1.41 & 1.40 \\
180 & 1.48 & 1.49 & & 1.48 & 1.49 & & 1.50 & 1.49 \\
200 & 1.57 & 1.56 & & 1.57 & 1.55 & & 1.59 & 1.57 \\
220 & 1.65 & 1.63 & & 1.64 & 1.61 & & 1.67 & 1.64 \\
240 & 1.72 & 1.70 & & 1.72 & 1.67 & & 1.75 & 1.71 \\
260 & 1.79 & 1.76 & & 1.79 & 1.72 & & 1.83 & 1.78 \\
280 & 1.86 & 1.82 & & 1.86 & 1.78 & & 1.90 & 1.85 \\
300 & 1.93 & 1.88 & & 1.92 & 1.82 & & 1.97 & 1.91 \\
320 & 2.00 & 1.94 & & 1.99 & 1.87 & & 2.04 & 1.97 \\
\hline
\end{tabular}




\section{IDENTIFICATION OF GROWTH RINGS}

It was possible to identify 6 growth rings through the analysis of sagittae and asterisci of $D$. brevirostris (Table 7). Growth rings were identified in all sagittae (100\%). The deposition of growth material is higher in a region on the dorsal margin that runs from the middle part of the otolith to the postrostrum, for this reason growth rings can be easily appreciated in this part of the sagittae (Fig. $3)$.

Table 6. Relationship between total fish length and length (LL) and width (LW) of the lapillus of Diapterus brevirostris / Relaciones entre el largo total del pez y el largo (LL) y ancho (LW) del lapillus de Diapterus brevirostris

\begin{tabular}{llccccc}
\hline \multicolumn{2}{c}{ Total length $(\mathrm{mm})$} & $\mathrm{a}$ & $\mathrm{b}$ & $\mathrm{n}$ & $\mathrm{R}^{2}$ & $\mathrm{~F}$ \\
\hline LL $(\mathrm{mm})$ & Both sexes & 0.102 & 0.516 & 118 & 0.755 & 357.73 \\
& Females & 0.106 & 0.509 & 39 & 0.848 & 207.12 \\
& Males & 0.093 & 0.537 & 37 & 0.678 & 73.59 \\
LW (mm) & Both sexes & 0.137 & 0.459 & 118 & 0.753 & 353.92 \\
& Females & 0.187 & 0.400 & 39 & 0.781 & 132.32 \\
& Males & 0.117 & 0.489 & 37 & 0.759 & 110.52
\end{tabular}

$\mathrm{a}=$ origin ordinate of relation, $\mathrm{b}=$ slope of relation, $\mathrm{n}=$ number of individuals, $\mathrm{R}^{2}=$ determination index of relation, $\mathrm{F}^{\prime}=$ Fischer index of relation
In asterisci, growth rings run from the dorsal to the ventral margin on the outer side of the otolith they look as dark concentric lines (Fig. 4). In $70 \%$ percent of asterisci the same number of rings were observed as in sagittae, in the remaining $30 \%$ growth rings were not clearly identified as growth rings.

Growth rings identification by transmitted light transparency was very difficult in lapilli because of the thickness of this structure.

\section{Discussion}

Six age groups were identified in the sagittae and asterisci; it is important to evaluate the growth period of time of each ring to refer them to each age group. With this information growth studies are carried out which render in the growth constants of von Bertalanffy's equation, which are used to formulate future models in maximum sustainable yield and catch predictions. This allows an adequate management of the fishery, avoiding its overfishing.

The relationship between the fish length and the length and width of the three pairs of otoliths showed that these structures are adequate to determine age of the species

Table 7. Number of rings on sagittae and asteriscus and average length of Diapterus brevirostris and data from other species of the Gerreidae family $(\mathbf{m m})$ / Número de anillos en las sagittae y los asteriscus, y el largo promedio de Diapterus brevirostris y datos de otras especies de la familia Gerreidae $(\mathrm{mm})$

\begin{tabular}{|c|c|c|c|c|c|c|c|}
\hline & Colima & Costa Rica & $\begin{array}{c}\text { Colima and } \\
\text { Jalisco }\end{array}$ & $\mathrm{Co}$ & mbia & Japan & Campeche \\
\hline & Diapterus & Diapterus & Coum 3 & Eugerre & plumieri $^{4}$ & Gerres & Diapterus \\
\hline & brevirostris ${ }^{l}$ & $\begin{array}{l}\text { peruvlanus } \\
\text { (brevirostris) }\end{array}$ & Gerres cinereus & Males & Females & oyena $^{5}$ & rhombeus ${ }^{6}$ \\
\hline 1 & 100 & 81 & 167.6 & 143 & 148 & 102.9 & 199.8 \\
\hline 2 & 150 & 112 & 226.7 & 156 & 163 & 119.8 & 202.0 \\
\hline 3 & 190 & 172 & 300.0 & 168 & 177 & 134.0 & 203.1 \\
\hline 4 & 230 & 226 & 353.3 & 179 & 190 & 145.8 & 203.5 \\
\hline 5 & 260 & 251 & 398.3 & 186 & 206 & 155.6 & 203.8 \\
\hline 6 & 290 & & 432.5 & & & 163.9 & 203.9 \\
\hline 7 & & & 444.0 & & & 170.7 & 204.0 \\
\hline 8 & & & & & & 176.5 & 204.0 \\
\hline
\end{tabular}

${ }^{1}$ this study, ${ }^{2}$ Cabrera-Peña et al. (1996), ${ }^{3}$ Espino-Bar et al. (2014), ${ }^{4}$ Olaya-Nieto \& Appeldoorn (2004),

${ }^{5}$ Kanak \& Tachihara (2006), ${ }^{6}$ Ayala-Pérez et al. (2001) 
and that they are equivalent of their growth, both the otoliths and the fish. The growth ring identifications were done with the analysis of the sagittae and asterisci. In the case of the lapilli, due to its shape and thickness, this identification could not be done by transparency, therefore a future technique should be carried out by cutting and polishing to a level at which the rings can be observed. In fact, during the larvae stage, the three pairs of otoliths show a discoid structure, where the daily growth rings are observed, and as time go by to the adult stage, the otoliths grow in length and thickness. In the case of the lapilli, this growth prevents the observation of seasonal growth rings in the lapilli (Victor \& Brothers 1982, Brothers et al. 1983).

Also worth mentioning, during the growth process, as the fish ages, the deposition of the calcium carbonate and otoline vary, being increasingly erratic and eccentric to the core, so that a greater amount of material is deposited in the postrostrum than in the rostrum, and the dorsal margin of the sagitta grows more than the ventral border. All this means that the otoliths grow increasingly curved as the fish ages, and identifying the latter growth rings is more difficult.

The number of studied otoliths varies depending on whether it is the sagitta, asteriscus or lapillus, due to the difficulty of extraction. Often sagittae are broken because of its large size and the cut made on the base of the skull. Other occasions the semicircular canals tear during the extraction and the lapilli are lost. During the liberation and cleaning of the otoliths from the sacculus, lagena or utriculus, otoliths can break, as it occurs mainly with asterisci. Therefore the otolith extraction has to be done very carefully from each of the chambers.

The 3 pairs of otoliths show morphologic differences between right and left and by sexes, but this difference was not statistically significant. Growth of sagittae and lapilli is higher in males than females from 160 to $320 \mathrm{~mm}$. Growth in asterisci is higher in females than in males from 180 to $320 \mathrm{~mm}$.

Cabrera-Peña et al. (1996) calculated age growth rings of $D$. peruvianus ( $=D$. brevirostris) in the coastal lagoons of rivers Damas and Palo Alto in Costa Rica by length frequency analysis; they found 5 growth rings with a medium length similar to those found in the present paper (Table 7).

Medium length at each age or growth rings were obtained by different authors for different members of the Gerreidae family (Table 7). Kanak \& Tachihara (2006) found small lengths for each age group for Gerres oyena in Okinawa Island in Japan. Also, Romero \& González (1986) reported small sizes for each age in Eugerres plumieri for both cases: males and females. Ayala-Pérez et al. (2001) found small sizes at each age for D. rhombeus in the Lagoon of Terminos, Campeche, Mexico. LópezMartínez et al. (2011) reported for Eucinostomus currani in the Gulf of California small sizes: $114 \mathrm{~mm}$ for 0.9 years, $137 \mathrm{~mm}$ for 1.2 years, $156 \mathrm{~mm}$ for 1.6 years and $180 \mathrm{~mm}$ for 2.2 years.

Data on number of growth rings found in the present paper are bigger in relationship of those mentioned above, but $D$. brevirostris reached smaller sizes than those reported for G. cinereus in the coast of Colima and Jalisco (Espino-Barr et al. 2014).

According to Chávez-Comparán \& Hammann (1989), $D$. brevirostris and G. cinereus in the Cuyutlan Lagoon in Colima State, are considered to be both omnivorous but G. cinereus feeds principally upon benthic invertebrates while $D$. peruvianus $(=D$. brevirostris $)$ also feeds on planktonic preys, which means that this species has a wider range of food spectrum of preys in its diet. These food habits help both species reduce the degree of competition between them.

A higher number of growth rings of $D$. brevirostris were found in Cuyutlán Lagoon, Colima, than in Costa Rica coasts. This can be explained by Taylor's theory (1958, 1960), who establishes that organisms of the same species are less long-lived and present fewer age groups as they locate closer to the equator, its longevity diminishes the same as the latitude.

\section{LiTERATURE CITED}

Aguirre-León A \& S Díaz-Ruiz. 2000. Estructura poblacional, madurez gonádica y alimentación de Eugerres plumieri (Gerreidae) en el sistema fluvio-deltaico Pom-Atasta, México. Population structure, gonadal maturity and feeding habits of Eugerres plumieri (Gerreidae) in the Pom-Atasta fluvial-deltaic system, Mexico. Ciencias Marinas 26(2): 253-273.

Aguirre-León A \& S Díaz-Ruiz. 2006. Estructura de tallas, madurez gonádica y alimentación del pez Diapterus rhombeus (Gerreidae) en el sistema fluvio-deltaico PomAtasta, Campeche, México. Revista de Biología Tropical 54(2): 599-611.

Allen GR \& DR Robertson. 1994. Peces del Pacífico Oriental Tropical, 327 pp. CONABIO, Agrupación Sierra Madre y CEMEX,México. 
Álvarez-Hernández JH. 1999. Edad y crecimiento de la mojarra Gerres cinereus en la costa sur del estado de Quintana Roo, México. Proceedings of the 45th Gulf Caribbean Fisheries Institute, pp. 514-523.

Álvarez-Pliego N. 2009. Análisis filogenético y biogeográfico de los peces del género Diapterus Ranzani, 1842 (Percoidei: Gerreidae). Tesis doctoral. CICIMAR, IPN, La Paz, 129 pp.

Aurioles GD. 1988. Behavioral ecology of California sea lion Zalophus californianus in the Bay La Paz, Baja California Sur, México. Journal of Mammalogy 65(3): 519-521.

Avilés-Torres S, JJ Schmitter-Soto \& RC BarrientosMedina. 2001. Patrones espaciales de la riqueza de peces en lagunas costeras del sur de Quintana Roo, México. Hidrobiológica 11(2): 141-148.

Ayala-Pérez LA, BA Gómez-Montes \& J Ramos-Miranda. 2001. Distribución, abundancia y parámetros poblacionales de la mojarra Diapterus rhombeus (Pisces: Gerreidae) en la Laguna de Términos, Campeche, México. Revista de Biología Tropical 49(2): 635-642

Bailey KM \& DG Ainley. 1982. The dynamics of California sea lion predation on Pacific hake. Fisheries Research 1: 163-176.

Beamish RJ \& GA McFarlane. 1983. The forgotten requirement for age validation in Fisheries Biology Transactions of American Fishery Society 112:735-743.

Barkman RC. 1978. The use of otolith growth rings to age young Atlantic silversides, Menidia menidia. Transactions of the American Fisheries Society 107: 790-792.

Begg GA, SE Campana, AJ Fowler \& IM Suthers. 2005. Otolith research and application: current directions in innovation and implementation. Marine and Freshwater Research 56(5): 477-483.

Berg E, TH Sarvas, A Harbitz, SE Fevolden \& AB Salberg. 2005. Accuracy and precision in stock separation of northeast Arctic and Norwegian coastal cod by otoliths comparing readings, image analyses and a genetic method. Marine and Freshwater Research 56(5): 753-762.

Bolz GR \& RG Lough. 1983. Larval cod (Gadus morhua) and haddock (Melanogrammus aeglefinus) growth on Georges Bank, spring 1981. Fishery Bulletin 81: 827-836.

Bolz GR \& RG Lough. 1988. Growth through the first six months of Atlantic cod, Gadus morhua, and haddock, Melanogrammus aeglefinus, based on daily otolith increments. Fishery Bulletin 86: 223-236.

Brothers EB, ED Prince \& DW Lee. 1983. Age and growth of young-of-year bluefin tuna, Thunnus thynnus, from otolith microstructure. In: Prince ED \& LM Pulos (eds). Age determination of oceanic pelagic fishes: tunas, billfishes, and sharks. NOAA Technical Reports NMFS 8: 49-60.

Brown EG \& GJ Pierce. 1997. Diet of harbour seals at Mousa, Shetland, during the third quarter of 1994. Journal of the Marine Biological Association of the United Kingdom 77: 539-555.
Bussing WA. 1995. Gerreidae, Mojarras. In: Fischer W, F Krupp, W Schneides, C Sommer, KE Carpenter \& UH Niem (eds). Guía FAO para la identificación de especies para los fines de la pesca. Pacífico Centro Oriental. Vertebrados 2 y 3: 1114-1128. FAO, Roma.

Caballero-Vázquez JA, HC Gamboa-Pérez \& JJ SchmitterSoto. 2005. Composition and spatio-temporal variation of the fish community in the Chacmochuch Lagoon system, Quintana Roo, Mexico. Composición espacio-temporal de la comunidad de peces en el Sistema Lagunar Chacmochuch, Quintana Roo, México. Hidrobiológica 15(2), especial: 215-225.

Cabrera-Peña J, Y Solano-López \& M Mora-Hernández. 1996. Crecimiento de Diapterus peruvianus (Pisces: Gerridae) en los estuarios de los ríos Damas y Palo Seco, Costa Rica. Revista de Biología Tropical 44(2): 935-937.

Campana SE \& JD Neilson. 1985. Microestructure of fish otoliths. Canadian Journal of Fisheries and Aquatic Sciences 44: 1014-1032.

Carlström D. 1963. A crystallographic study of vertebrate otoliths. The Biological Bulletin 125: 441-463.

Casselman JM. 1983. Age and growth assessment of fish from their calcified structures - techniques and tools. NOAA Technical Report NMFS 8: 1-17.

Castillo-Rivera M, M Montiel, L Sanvicente-Añorve \& R Zárate. 2005. Spatial, seasonal and diel distribution patterns of two species of mojarras (Pisces: Gerreidae) in a Mexican tropical coastal lagoon. Journal of Applied Ichthyology 21(6): 498-503.

Chávez-Comparán JC \& MG Hammann. 1989. Dieta de las mojarras, Gerres cinereus y Diapterus peruvianus (Pisces: Gerreidae) en la Laguna de Cuyutlán, Colima, México, durante verano. Diet of the mojarras, Gerres cinereus and Diapterus peruvianus (Pisces: Gerreidae) in Cuyutlán Lagoon, Colima, Mexico, during summer. Ciencias Marinas 15(3): 71-80.

Chen WJ, R Ruiz-Carus \& G Ortis. 2007. Relationships among four genera of mojarras (Teleostei: Perciformes: Gerreidae) from the western Atlantic and their tentative placement among percomorph fishes. Journal of Fish Biology 79 (Suppl. B): 202-218.

Daniel WW. 1991. Bioestadística. Base para el análisis de las ciencias de la salud, 667 pp. Ed. Noriega-Limusa, México.

David AW, JJ Isely \& CB Grimes. 1994. Differences between the sagitta, lapillus, and asteriscus in estimating age and growth in juvenile red drum, Sciaenops ocellatus. Fishery Bulletin 92: 509-515.

Degens ET, WG Deuser \& RL Haedrich. 1969. Molecular structure and composition of fish otoliths. Marine Biology 2(2): 105-113.

Díaz-Murillo BP. 2010. Otolitos sagitta de especies selectas de Gerreidae (Teleostei: Perciformes): variación interespecífica y su aplicación taxonómica. Tesis Maestría en Ciencias, CICIMAR-IPN, La Paz, 82 pp. 
Ehrhardt N. 1981. Curso sobre métodos en dinámica de poblaciones. 1a. Parte. Estimación de parámetros poblacionales, $150 \mathrm{pp}$. Instituto Nacional de la Pesca, México.

Eide A \& A Wikan. 2010. Optimal selection and effort in a fishery on a stock with cannibalistic behavior: the case of the Northeast Arctic cod fisheries. Journal of Fisheries and Aquatic Science 5(6): 454-468.

Espino-Barr E, EG Cabral-Solís, M Gallardo-Cabello \& AL Ibáñez-Aguirre. 2005. Age determination of Mugil curema Valenciennes, 1836 (Pisces: Mugilidae) in the Cuyutlán Lagoon, Colima, Mexico. International Journal of Zoological Research 1: 21-25.

Espino-Barr E, M Gallardo-Cabello, A Garcia-Boa, EG Cabral-Solís \& M Puente-Gómez. 2006. Morphologic and morphometric analysis and growth rings identification of otoliths: sagitta, asteriscus and lapillus of Caranx caninus (Pisces: Carangidae) in the coast of Colima, Mexico. Journal of Fisheries and Aquatic Science 1(2): 157-170.

Espino-Barr E, M Gallardo-Cabello, K Granados-Flores, EG Cabral-Solís, A Garcia-Boa \& M Puente-Gómez. 2010. Growth analysis of Microlepidotus brevipinnis from the Pacific coast of Jalisco, Mexico. Journal of Fisheries and Aquatic Science 5(4): 293-303.

Espino-Barr E, M Gallardo, EG Cabral-Solís, M PuenteGómez \& A Garcia-Boa. 2014. Growth of the Yellowfin Mojarra Gerres cinereus off the Pacific coast of Mexico. Journal of Fisheries and Aquatic Science 9(1): 14-23. <doi: 10.3923/jfas.2014>

Francis C, SJ Harley, SE Campana \& P Doering-Arjes. 2005. Use of otolith weight in length-mediated estimation of proportions at age. Marine and Freshwater Research 56(5): 735-743.

Gallardo-Cabello M. 1986. Estudio de la ultraestructura del otolito sagita de la brótola Phycis blennoides (Brunnich, 1768) en el Mediterráneo occidental (Pisces: Gadidae). Anales del Instituto de Ciencias del Mar y Limnología, UNAM 13(2): 197-206.

Gallardo-Cabello M, E Espino-Barr, F González-Orozco \& A Garcia-Boa. 2003. Age determination of Anisotremus interruptus (Gill, 1863) (Perciformes: Haemulidae) by reading scales, in the coast of Colima, México. International Journal of Tropical Biology 51(2): 519-528.

Gallardo-Cabello M, E Espino-Barr, A Garcia-Boa, EG Cabral-Solís \& M Puente-Gómez. 2006. Morphologic and morphometric analysis and growth rings identification of otoliths: sagitta, asteriscus and lapillus of Caranx caballus (Pisces: Carangidae) in the coast of Colima, Mexico. International Journal of Zoological Research 2(1): 34-47.

Gallardo-Cabello M, E Espino-Barr, A Garcia-Boa, EG Cabral-Solís \& M Puente-Gómez. 2007. Study of the growth of the green jack Caranx caballus Günther 1868, in the coast of Colima, Mexico. Journal of Fisheries and Aquatic Science 2(2): 130-139.
Gallardo-Cabello M, E Espino-Barr, RA Nava-Ortega, A Garcia-Boa, EG Cabral-Solís \& M Puente-Gómez. 2011. Analysis of the otoliths of sagitta, asteriscus and lapillus of Pacific sierra Scomberomorus sierra (Pisces: Scombridae) in the coast of Colima, Mexico. Journal of Fisheries and Aquatic Science 6(4): 390-403.

Gallo-Reynoso JP \& D Aurioles-Mendoza. 1984. Distribución y estado actual de la población de foca común (Phoca vitulina richardsi Gray, 1864) en la península de Baja California, México. Anales del Instituto de Biología de la UNAM Serie. Zoología 55(2): 323-332.

Gómez del Prado-Rosas MC, JN Álvarez-Cadena, R Lamothe-Argumedo, U Ordóñez-López \& AR AlmaralMendivil. 2007. Larvas de peces parasitadas por metacercarias de Hemiuridae y Fellodistomidae (Trematoda) en la laguna arrecifal de Puerto Morelos, Quintana Roo, México. Hidrobiológica 17(3): 233-239.

González-Acosta AF, J de la Cruz-Agüero \& JL CastroAguirre. 2005. A review of eastern Pacific species of the genus Eugerres (Perciformes: Gerreidae). Bulletin of Marine Science 76(3): 661-673.

González-Acosta AF, P Béarez, N Álvarez-Pliego, J de la Cruz-Agüero \& JL Castro-Aguirre. 2007. On the taxonomic status of Diapterus peruvianus (Cuvier, 1830) and reinstatement of Diapterus brevirostris (Sauvae, 1879)(Teleostei: Gerreidae). Cybium 31(3): 369-377.

Granados-Flores K, M Gallardo-Cabello, E Espino-Barr \& EG Cabral-Solís. 2010. Age determination of Microlepidotus brevipinnis (Steindachner, 1869) (Pisces: Haemulidae) in the coast of Jalisco, Mexico, by reading otoliths and scales. International Journal of Zoological Research 6(1): 1-12.

Halpern BS. 2004. Are mangroves a limiting resource for two coral reef fishes? Marine Ecology Progress Series 272: $93-$ 98.

Heald MJ \& DFS Griffiths. 1967. La determinación por medio de la lectura de escamas, de la edad de la sardina Sardinella anchovia, del Golfo de Cariaco, Venezuela Oriental. Serie Recursos y Explotación Pesquera 1(10): 374-422.

Hernández RE, MA Perera, A Castillo, E Luna, JA de la Cruz, LM Gómez \& J Valdez-Zenil. 2012. Embyonic and larval development of Eugerres mexicanus (Perciformes: Gerreidae) in Tenosique, Tabasco, Mexico. Revista de Biología Tropical 60(1): 369-379.

Herrera-Reveles AT, M Lemus \& B Marín. 2012. Crecimiento somático y relación ARN/ADN en estadios juveniles de Eucinostomus argenteus (Pisces: Gerreidae) en dos localidades del Caribe de Venezuela. Revista de Biología Tropical 60(Suppl. 1): 151-163.

Hickling CF. 1931. The structure of the otolith of the hake. Quarterly Journal of Microscopical Science 74: 547-561.

Holst E, H Kaiser, L Schoen, G Roebig \& G Göldner. 1950. Die Arbeitsweise de Statolithenapparates bei Fischen. Zeitschrift für Verglaichende Physiologie 32: 60-120. 
Jearld A. 1983. Age determination. In: Nielsen LA \& DL Johnson (eds). Fisheries techniques, 301-324 pp. American Fishery Society. Southern Printing, Virginia.

Jiménez-Rosenberg SPA, E González-Navarro \& RJ Saldierna-Martínez. 2003. Larval, pre-juvenile and juvenile development of Diapterus peruvianus (Perciformes: Gerreidae). International Journal of Tropical Biology 51(2): 479-488.

Jones DL, JF Walter, EN Brooks \& JE Serafy. 2010. Connectivity through ontogeny: fish population linkeages among mangrove and coral reef habitats. Marine Ecology Progress Series 401: 245-258.

Joseph DC. 1962. Growth characteristics of two Southern California Srffishes, the California Corbina and Spotfin Croaker, Family Sciaenidae. The Resources Agency of California Dep. of Fish and Game, Fish Bulletin 119: 1-54.

Kamaruzzaman BY, Z Rina, BA John \& KCA Jalal. 2011. Heavy metal accumulation in commercially important fishes of south west Malaysian coast. Research Journal of Environmental Sciences 5: 595-602.

Kanak MK \& K Tachihara. 2006. Age and growth of Gerres oyena (Forsskål, 1775) on Okinawa Island, Japan. Journal of Applied Ichthyology 22(4): 310-313.

Laevesteu T \& F Favorite. 1981. Fluctuations on herring stocks in the eastern Bering Sea as revealed by ecosystem model (Dinumes III) ICES Symposium on the Biological Basis on Pelagic Fish Stock Management 5: 1-177.

Lagardere F. 1989. Influence of feeding conditions and temperature on the growth rate and otolith-increment deposition of larval Dover sole (Solea solea) (L.). Rapport et Procès- Verbaux des Reunion du Conseil Permanent International pour l'Explorations de la Mer 191: 390-399.

Lagler KF, JE Bardach \& RR Miller. 1962. Ichthyology, 495 pp. The University of Michigan, John Wiley and Sons, New York.

Le Boeuf BJ \& ML Bonnell. 1980. Pinnipeds of the California Islands: Abundance and distribution. In: Power DM (ed). The California Island: Proceeding of Multidisciplinay Symposium, Sta. Barbara, pp. 475-491.

Le Boeuf BJ, GD Aurioles, C Condit, C Fox, R Gisiner, R Romero \& F Sinset. 1983. Size and distribution of the California sea lion (Zalophus californianus) populations in México. Proceeding of California Academy of Sciences 42: $77-85$.

López-Martínez J, J Rodríguez-Romero, NY HernándezSaavedra \& E Herrera-Valdivia. 2011. Population parameters of the Pacific flagfin mojarra Eucinostomus currani (Perciformes: Gerreidae) captured by shrimp trawling fishery in the Gulf of California. International Journal of Tropical Biology 59(2): 887-897.

Lowenstein O. 1957. The sense organs, the acusticolateralis system. In: Brown ME (ed). The physiology of fishes, pp. 155-186. Academic Press, New York.
Martínez-González JE. 1983. Distribución y abundancia de la familia Gerreidae (Pisces) en la plataforma continental de los estados de Guerrero y Nayarit, México, 1982. Tesis Licenciatura, Facultad de Ciencias, UNAM, México, 107 pp.

Mascareña-Osorio I, O Aburto-Oropeza \& EF Balart. 2003. Otolitos de peces de arrecife del Golfo de California, 120 pp. UABCS y CIBNOR, México.

Mendenhall W. 1987. Introduction to probability and statistics, 884 pp. PWS-Kent Publishing, Boston.

Mugiya Y. 1964. Calcification in fish and shell-fish Seasonal occurrence of a pre-albumin fraction in the otolith fluid of some fish corresponding to the period of opaque zone formation in their otoliths. Bulletin of the Japanese Society of Scientific Fisheries 30: 445-467.

Mugiya Y. 1966a. Calcification in fish and shell-fish. A study on paper electophoretic patterns of the acid mucopolysaccharides and Pas-positive materials in the otolith fluid of some fish. Bulletin of the Japanese Society of Scientific Fisheries 32: 117-129.

Mugiya Y. 1966b. Calcification in fish and shell-fish. Seasonal change in calcium and magnesium concentration of the otolith fluid in some fish with special reference to the zone formation of their otolith. Bulletin of the Japanese Society of Scientific Fisheries 32: 549-557.

Olaya-Nieto CW \& RS Appeldoorn. 2004. Edad y crecimiento de la mojarra rayada, Eugerres plumieri (Cuvier), en la Ciénega Grande de Santa María, Colombia. Gulf and Caribbean Fisheries Institute 55: 337-347.

Ospina-Arango JF, FI Pardo-Rodríguez \& R Álvarez-León. 2008. Madurez gonadal de la ictiofauna presente en la Bahía de Cartagena, Caribe Colombiano. Boletín Científico del Centro de Museos, Museo de Historia Natural 12: 117140.

Romero MR \& LW González. 1986. Edad y crecimiento de la mojarra, Eugerres plumieri (Cuvier en C. y V., 1830) (Pisces: Gerridae), de la Laguna de la Restinga, Isla de Margarita, Venezuela. Boletín del Instituto Oceanográfico 25(1/2): 2134.

Santana-Hernández H, E Espino-Barr, M Gallardo-Cabello \& A Garcia-Boa. 2008. Morphologic and morphometric analysis and growth rings identification of otoliths: sagitta, asteriscus and lapillus of yellowfin tuna Thunnus albacares (Bonaterre, 1788) (Pisces: Scombridae) in the Eastern Pacific. International Journal of Zoological Research 4(3): 138-151.

Sasaki H \& J Miyata. 1955. Experimentelle studien über Otolithen. Zeitschrift für Laryngologie, Rhinologie, Otologie und ihre Grenzgebiete 34: 740-748.

Secor BW, JM Dean \& EH Laban. 1992. Otolith removal and preparation for microstructural examination. In: Stevenson DK \& SE Campana (eds). Otolith microstructure examination and analysis. Canadian Special Publication of Fisheries and Aquatic Sciences 117: 19-57. 
Solomon G, K Matsushita, M Shimizu \& Y Nose. 1985. Age and growth of rose bitterling in Shin Tone River. Bulletin of the Japanese Society of Scientific Fisheries 51: 55-62.

Sparre P \& SC Venema. 1995. Introducción a la evaluación de recursos pesqueros tropicales. Parte 1 - Manual. FAO Documentos Técnicos de Pesca 306/1: 1-420.

Stevensen DK \& SE Campana. 1992. Otolith microstructure examination and analysis. Canadian Journal of Fisheries and Aquatic Sciences 117: 1-126.

Suthers IM, KT Frank \& SE Campana. 1989. Spatial comparison of recent growth in postlarval Atlantic cod (Gadus morhua) off southwestern Nova Scotia: inferior growth in a presumed nursery area. Canadian Journal of Fisheries and Aquatic Sciences 46(1): 113-124.
Tapia-García M \& G Ayala-Pérez. 1996-1997. Clave para la determinación de las especies de mojarras de México (Pisces: Gerreidae). Revista de Biología Tropical 44(3)/45(1): 519526.

Taylor CC. 1958. Cod growth and temperature. Journal du Conseil 23(3): 366-370.

Taylor CC. 1960. Temperature, growth and mortality - the Pacific cockle. Journal du Conseil 26(1):117-124.

Victor BC \& EB Brothers. 1982. Age and growth of the fallfish Semotilus corporalis with daily otolith increments as a method of annulus verification. Canadian Journal of Zoology 60: 2543-2550.

Zar JH. 1996. Biostatistical analysis, 662 pp. Prentice Hall, Englewood Cliffs.

Received 17 June 2013 and accepted 14 April 2014

Associate Editor: Mauricio Landaeta D. 